\title{
MEMBEDAH KOMODIFIKASI ISI PESAN MINI DRAMA LINE "NIC AND MAR" (ANALISIS SEMIOTIKA JOHN FISKE TERHADAP MINI DRAMA LINE)
}

\author{
Indra Hutami, Freddy Yusanto, Catur Nugroho
}

\author{
Prodi Ilmu Komunikasi, Fakultas Komunikasi dan Bisnis, \\ Universitas Telkom \\ hutamiindra1@gmail.com
}

\begin{abstract}
Mobile mini drama of the Line is a mini-series that narrate the characters who play a part in a story which has drama genre. One of them is a mobile mini drama Line "Nic and Mar" designed to meet the needs of the people of Indonesia will of entertainment that can be enjoyed anytime, anywhere for free just by using the gadget. However, the facts behind their mobile mini dramas which incidentally can be enjoyed free, able to bring great benefits in terms of economy for the media Line. Researchers interested in studying this phenomenon because the researchers identified that there has been a process of commodification and wanted to know what kind of shape the commodification. The purpose of this research is to determine how to shape the content of the message commodification Mini Drama Line "Nic and Mar". The approach of the research is qualitative, uses a semiotic analysis to analyze the research object. The data analysis technique is based from "The Codes of Television" by John Fiske. The research result is in Mini Drama Line "Nic and Mar" there are audio aspect and visual aspect that formed by videography techniques so that it becomes a spectacle, but the signs are there in processed into a product so that the scene in this drama mini formed into commodities. The function changed, initially the storyline is used for forming part mini-drama story, now the storyline also serves as a exchange rate.
\end{abstract}

Keywords: commodification, semiotic, codes of television, Line's Mini Drama 


\begin{abstract}
Abstrak
Mobile mini drama dari Line merupakan sebuah mini seri yang mengkisahkan tokohtokoh yang berperan di dalam sebuah cerita bergenre drama. Salah satunya adalah mobile mini drama Line "Nic and Mar" yang dibuat untuk memenuhi kebutuhan masyarakat Indonesia akan hiburan yang dapat dinikmati kapan saja, dimana saja secara gratis hanya dengan menggunakan gadget. Akan tetapi, fakta dibalik mobile mini drama yang notabenenya dapat dinikmati secara gratis ini mampu membawa keuntungan yang besar dari segi ekonomi untuk media Line. Peneliti tertarik untuk meneliti fenomena ini dikarenakan peneliti mengidentifikasi bahwa telah terjadi proses komodifikasi dan ingin mengetahui seperti apa bentuk komodifikasi tersebut. Tujuan dari penelitian ini adalah untuk mengetahui bagaimana bentuk komodifikasi isi pesan Mini Drama Line "Nic and Mar". Penelitian ini menggunakan pendekatan kualitatif dengan menggunakan analisis semiotika untuk menganalisis objek yang diteliti. Teknik analisis data dilakukan berdasarkan teori yang dikemukakan oleh John Fiske yaitu "The Codes of Television". Dari hasil penelitian ini dapat disimpulkan bahwa dalam mini drama ini dibentuk berdasarkan aspek visual dan audio dan menjadi sebuah tontonan, namun tanda-tanda yang ada di dalamnya diolah menjadi sebuah produk sehingga scene dalam mini drama ini dibentuk menjadi komoditas. Perubahan fungsipun terjadi, alur cerita yang berguna sebagai bagian pembentuk cerita mini drama ini kini juga berfungsi sebagai alat tukar.
\end{abstract}

Kata Kunci: komodifikasi, semiotika, kode-kode televisi, Mini Drama Line

\section{PENDAHULUAN}

Teknologi di zaman sekarang terus berkembang, salah satunya dari teknologi analog yang kini berkembang menjadi teknologi digital. Berkembangnya teknologi analog ke teknologi digital dirasakan juga dalam ranah media yang dikenal dengan new media dan salah satu bentuk new media yang sering kita gunakan adalah internet. Orang-orang dapat berkomunikasi dengan berbasiskan internet caranya yaitu menggunakan instant messaging. Instant messaging sendiri merupakan bentuk aplikasi yang memfasilitasi penggunanya dalam berkirim pesan dalam bentuk teks, video maupun audio dan instant messaging dapat bersemayam di dalam ponsel, laptop, tablet, komputer. Global Web Index (GWI) mengeluarkan riset terbarunya mengenai penggunaan aplikasi instant messaging. Penelitian tersebut mengungkap bahwa telah terjadi peningkatan pengguna aplikasi instant messaging di Indonesia hingga 45\% sejak tahun 2013 hingga tahun 2014 (dikutip dari www.dailysocial.net tanggal 20 Oktober 2015 pukul 15:00 WIB). Saat ini orang lebih memilih untuk aktif di layanan pesan instant messaging yang memberikan kemudahan dalam berkirim pesan. Oleh karena itu, akan terjadi persaingan diantara penyedia-penyedia instant messaging untuk membuat orangorang memilih instant messaging mereka dibanding instant messaging pesaingnya. Semua aplikasi instant messaging memiliki keunikan masing-masing dalam menghadirkan layanan bertukar pesan dan juga dalam memasarkan dirinya.

Salahsatuaplikasiinstantmessagingyang selalu memberikan sesuatu yang berbeda dalam melakukan strategi pemasaran adalah Line. Line adalah sebuah aplikasi pengirim pesan instan gratis yang dapat 
digunakan pada berbagai platform seperti telepon cerdas, tablet, dan komputer. Salah satu yang dilakukan Line adalah di awal tahun 2015 Line meluncurkan mini drama berjudul "Nic and Mar". Mini drama yang memiliki tujuh episode ini mengkisahkan sepasang kekasih yang sudah lama tidak bertemu kemudian mereka bertemu lagi dalam situasi yang mereka tidak rencanakan awalnya. Latar dari mini drama ini adalah Kota Paris dan Praha. Untuk bisa berlangganan dan mengetahui update episode dari mini drama ini masyarakat harus memiliki akun Line terlebih dahulu kemudian akan terhubung ke situs www. youtube.com.

Galuh Chandrakirana selaku team leader of marketing Line Indonesia menampik asumsi bahwa drama Nic and Mar merupakan sebuah kampanye pemasaran tertentu. Line hanya ingin membuat sebuah hiburan gratis yang bisa dinikmati penggunanya hanya dengan menggunakan gadget mereka masing masing (Dikutip dari http://www.infokomputer.com/, pada tanggal 02 September 2015, pukul 19:00 WIB). Disamping asumsi asumsi tentang $\mathrm{Nic}$ and Mar, faktanya drama ini mampu menyita banyak perhatian dari masyarakat Indonesia. Dalam waktu sembilan hari perluncuran drama Nic and Mar berhasil memperoleh 1,1 juta viewers dan meningkat setiap harinya. Dari peluncuran episode pertamanya Line mampu meningkatkan jumlah penggunanya sebanyak $14 \%$. Pesan yang disampaikan melalui aspek audio dan visual menjadi komodifikasi bagi mini drama ini. Komodifikasi adalah sebuah proses merubah barang atau halhal yang awalnya adalah sebuah barang dengan nilai-nilai sosial di dalamnya dan berubah menjadi barang dengan nilai tukar atau nilai pasar di dalamnya (Mosco, 1996: 129). Peneliti tertarik meneliti tentang komodifikasi pada mini drama Line Nic and Mar. Bagaimana sebuah mini drama yang dibuat untuk memenuhi kebutuhan target pasarnya akan hiburan semata dan ditonton dengan cuma-cuma dapat membawa dampak besar di bidang ekonomi bagi Line itu sendiri. Tujuan dilakukannya penelitian ini adalah untuk mengetahui bentuk komodifikasi yang terjadi dalam Mini Drama Line "Nic and Mar".

\section{MEMANDANG IKLAN DALAM KONTEKS ILMU KOMUNIKASI}

Komunikasi merupakan salah satu aspek terpenting dan kompleks bagi kehidupan manusia. Manusia sangat dipengaruhi oleh komunikasi yang dilakukannya dengan orang lain baik sudah kenal maupun yang belum kenal satu sama lain (Stephen W. Littlejohn, \& Karen A. Foss dalam Theoris of Human Communication, 2008:2). Sepertiilmu-ilmu lainnya, ilmukomunikasi punmenyelidiki gejala komunikasi. Tidak hanya dengan pendekatan secara ontologis (apa itu komunikasi), tetapi juga secara aksiologis (bagaimana berlangsungnya komunikasi yang efektif) dan secara epistimologis (untuk apa komunikasi itu dilakukan). Pada hakikatnya proses komunikasi adalah proses penyampaian pikiran atau perasaan oleh seseorang (komunikator) kepada orang lain (komunikan) (Onong Uchjana Effendy dalam Ilmu Komunikasi Teori dan Praktek, 2009:9).

Mini Drama Line "Nic and Mar" dapat dinikmati atau ditonton di dalam ranah new media. Editor dari buku Handbook of New Media (Lievrouw Livingstone, 2006) menunjuk pada kesulitan untuk menyebutkn apa saja yang termasuk dalam media baru. Mereka memilih 
untuk mendefinisikan dengan cara yang berbeda, menggabungkan antara teknologi informasi dan komunikasi (ICT) dengan konteks sosial yang berhubungan dengan menyatukan tiga elemen: alat dan artefak teknologi; aktivas, praktik dan penggunaan; dan tatanan serta organisasi sosial yang terbentuk di sekeliling alat dan praktik tersebut. Ciri utama dari media baru yang paling utama adalah ketersalinghubungan, aksesnya terhadap khalayak individu sebagai penerima maupun pengirim pesan, interaksinya, kegunaannya yang beragam sebagai karakter yang terbuka dan sifatnya yang ada dimana-mana (McQuail, 2011:43).

Sementara itu dalam konteks komunikasi, periklanan adalah komunikasi komersil dan nonpersonal tentang sebuah organisasi dan produkproduknya yang ditransmisikan ke suatu khalayak target melalui media yang bersifatmassal seperti televisi, radio, koran, majalah, pengeposan langsung, reklame luar ruang, atau kendaraan umum. Dalam komunikasi global baru, pesan-pesan periklanan dapat ditransmisikan melalui media baru, khususnya internet (Monle Lee, 2007:3). Dalam analisis visual gambar menjadi suatu elemen terpenting yang menjadikannya bermakna. Ada dua aspek yang difokuskan dalam menganalisis iklan yakni aspek visual dan aspek audio. Kode-kode tersebut menginformasikan hampir seluruh aspek tentang keberadaan kita dan menyediakan konsep yang bermanfaat bagi analisis seni populer dan media (Berger, 2000: 33).

\section{PESAN MINI DRAMA SEBAGAI KOMODITAS}

Untuk dapat memahami konsep komodifikasi, kita harus memahami apa yang dimaksud dengan nilai guna dan nilai tukar terlebih dahulu. Menurut Adam Smith, nilai guna dan nilai tukar merupakan dua nilai yang dapat membedakan suatu produk. Nilai guna berasal dari kepuasan manusia atas keinginan atau kebutuhan tertentu, sedangkan nilai tukar didasarkan pada apa yang dapat dihasilkan produk dalam pertukaran. Komoditas adalah bentuk dari produk saat produksinya diatur melalui proses pertukaran tersebut. Komodifikasi adalah proses transformasi nilai guna menjadi nilai tukar (Mosco, 1996: 129). Komoditas adalah bentuk dari produk saat produksinya diatur melalui proses pertukaran tersebut. Komodifikasi adalah proses transformasi nilai guna menjadi nilai tukar (Mosco, 1996: 129).

Sejarah produksi surat kabar di masyarakat kapitalis melibatkan banyak proses, termasuk komodifikasi membuat seseorang yang memiliki kemampuan membuat cerita yang menjual tenaganya atau kemampuannya untuk menulis cerita, untuk diberi upah. Pemilik modal mengubah tenaga kerja menjadi sebuah karya berbentuk artikel koran atau kolom, bersama dengan cerita dan iklan lainnya, membentuk produk yang telah dikemas. Menjual surat kabar di pasar dan jika berhasil akan memperoleh yang kemudian dapat berinvestasi dengan memperluas bisnis surat kabar atau dengan berinvestasi dalam usaha lain yang menjanjikan penambahan modal.

Deskripsi singkat ini menunjukkan bahwa proses penciptaan nilai tukar dalam isi komunikasi menarik seluruh hubungan sosial ke dalam orbit komodifikasi, termasuk tenaga kerja, konsumen dan modal. Banyak penelitian telah mendokumentasikan nilai pendekataninidankesimpulannyabahwa media massa dalam masyarakat kapitalis 
telah memperluas proses produksi komoditi, antara lain menghasilkan pesan yang mencerminkan kepentingan pemilik modal (Mosco, 1996: 133-134).

\section{SEMIOTIKA DALAM ILMU KOMUNIKASI}

Dasar dari semiotika adalah konsep tentang tanda, tak hanya bahasa dan sistem komunikasi yang tersusun oleh tanda-tanda, melainkan dunia itu sendiri pun sejauh terkait dengan pikiran manusia seluruhnya terdiri atas tandatanda karena, jika tidak begitu, manusia tidak akan bisa menjalin hubungannya dengan realitas (Sobur, 2009:13). Tandatanda adalah perangkat yang kita pakai dalam upaya berusaha mencari jalan di dunia ini, di tengah-tengah manusia dan bersama-sama manusia. Semiotika atau dalam istilah Barthes, semiologi pada dasarnya hendak mempelajari bagaimana kemanusiaan (humanity) memaknai hal-hal (things). Memaknai (to signify) dalam hal ini tidak dapat dicampuradukkan dengan mengkomunikasikan (to communicate). Memaknai berarti bahwa objek-objek tidak hanya membawa informasi, dalam hal mana objek-objek itu hendak berkomunikasi, tetapi juga mengkonstitusi sistem terstruktur dari tanda (Barthes, 1988; Kurniawan, 2001:53).

\section{KOMODIFIKASI ISI DALAM IKLAN TV KOMERSIAL}

Komodifikasi adalah sebuah proses mentransformasikan nilai guna untuk digunakan sebagai sebuah produk berharga yang bisa dijadikan nilai tukar. "Commodification is the process of transforming things valued for their use into marketable products that are valued for what they can bring in exchange", paparnya.
Sebelum memahami komodifikasi lebih jauh lagi, kita harus memahami dulu apa yang dimaksud dengan nilai guna dan nilai tukar terlebih dahulu. Menurut Adam Smith, nilai guna dan nilai tukar merupakan dua nilai yang dapat membedakan suatu produk. Nilai guna berasal dari kepuasan manusia atas keinginan atau kebutuhan tertentu, sedangkan nilai tukar didasarkan pada apa yang dapat dihasilkan produk dalam pertukaran. Komoditas adalah bentuk dari produk saat produksinya diatur melalui proses pertukaran tersebut. Komodifikasi terbagi dalam tiga bentuk, yaitu: komodifikasi isi media, komodifikasi audiens, dan komodifikasi pekerja (Mosco, 2009: 127).

Komodifikasi konten (isi media) adalah sebuah proses komodifikasi dalam komunikasi yang melibatkan transformasi pesan, mulai dari halhal kecil sampai sebuah sistem yang memiliki makna berarti, menjadi produk pasar (Mosco, 2009: 133).

\section{SEMIOTIKA JOHN FISKE}

Kode-kode televisi adalah teori yang dikemukakan oleh John Fiske atau yang biasa disebut kode-kode yang digunakan dalam dunia pertelevisian. Menurut Fiske, kode-kode yang muncul atau yang digunakan dalam acara televisi tersebut saling berhubungan sehingga terbentuk sebuah makna. Dalam kode-kode televisi yang diungkapkan dalam teori John Fiske (1987:5), bahwa peristiwa yang ditayangkan dalam dunia televisi telah di-en-kode oleh kode-kode sosial yang terbagi dalam tiga level sebagai berikut:

\section{Level Realitas (Reality)}

Kode sosial yang termasuk di dalamnya adalah appearance (penampilan), dress 
(kostum), make-up (riasan), environment (lingkungan), behavior (kelakuan), speech (cara berbicara), gesture (gerakan) dan expression (ekspresi).

\section{Level Representasi (Representation)}

Kode-kode sosial yang termasuk didalamnya adalah kode teknis, yang melingkupi camera (kamera), lighting (pencahayaan), editing (perevisian), music (musik) dan sound (suara). Serta kode representasi konvensional yang terdiri dari narative (naratif), conflict (konflik), character (karakter), action (aksi), dialogue (percakapan), setting (layar) dan casting (pemilihan pemain).

\section{Level Ideologi (Ideology)}

Kodesosial yangtermasukdidalamnya adalah individualism (individualisme), feminism (feminisme), race (ras), class (kelas), materialism (materialisme), capitalism (kapitalisme) dan lain-lain.

\section{METODOLOGI PENELITIAN}

Penelitian ini menggunakan metode penelitian kualitatif dengan paradigma kritis. Metode penelitian kualitatif dapat digunakan untuk meneliti pada kondisi obyek yang alamiah. Moleong menyimpulkan bahwa penelitian kualitatif merupakan penelitian yang bermaksud untuk memahami fenomena tentang apa yang dialami oleh subjek penelitian pada sesuatu konteks khusus yang alamiah dengan memanfaatkan berbagai metode ilmiah (2013:6). Paradigma kritis digunakan karena analisis kritis menekankan pada konstelasi kekuatan yang terjadi pada proses produksi makna dari Mini Drama Line "Nic and Mar". Penulis ingin melihat komodifikasi yang terjadi dalam mini drama tersebut secara lebih dalam dengan menggunakan pisau bedah analisis semiotika John Fiske.

Unit analisis yang dipilih dalam penelitian ini berupa scene-scene dari tiap episodenya dan mewakili atau merangkum alur cerita dari tujuh episode dan terdapat unsur komodifikasi, dengan aspek-aspek audio dan visual yang ada di dalamnya.

\section{HASIL DAN PEMBAHASAN}

\section{A. Episode 1}

Episode satu, dipilih tiga scene untuk menjadi unit analisis. Tiga scene tersebut yaitu scene satu, scene tiga, scene tujuh.

\section{Scene 1}

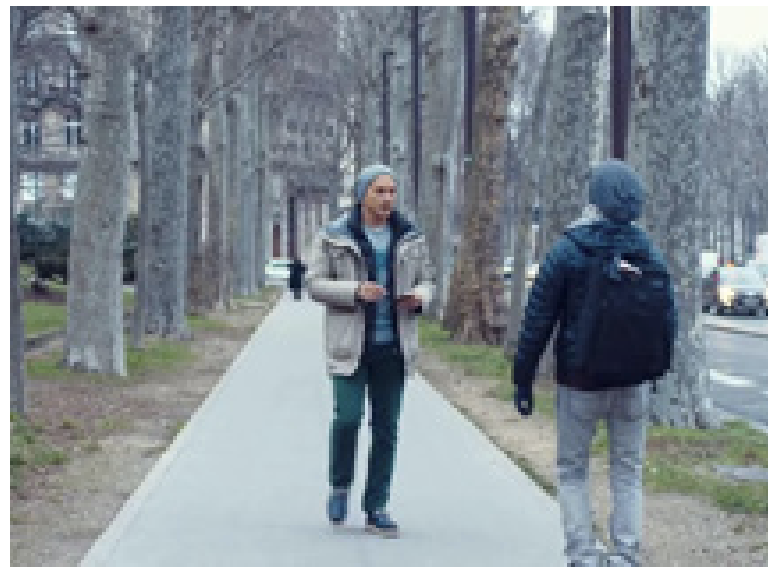

Gambar 1 scene satu episode satu

\section{Level Realitas}

Scene satu memperlihatkan keindahan bangunan-bangunan bersejarah di Kota Paris. Setelah itu muncul sesosok lelaki dengan penampilan casual mengenakan celana jeans berwarna hijau dengan sweater berwarna biru kehijau-hijauan yang diluarnya dipakaikan jaket yang terlihat cukup tebal, dia menggunakan kupluk dengan warna yang senada dengan warna sweaternya berjalan seorang diri di trotoar. Dia adalah Nic, pemeran utama pria dalam mini drama ini. 


\section{Level Representasi}

Adegan Nic berjalan di trotoar menggunakan teknik pengambilan gambar Eye Level dengan ukurang gambar Long Shot. Eye Level dinyatakan Iskandar (2011) sebagai sudut pandang pengambilan gambar sejajar dengan objek. Eye Level tidak memberikan kesan dramatis kerena dalam kondisi shoot yang biasa-biasa saja yang dapat memperlihatkan ekspresi dan gerakan tubuh dari sang aktor. Dengan teknik pengambilan gambar ini beberapa kali juga dapat memperlihatkan keadaan sekitar dimana aktor berada. Dalam scene ini banyak memperlihatkan keindahankeindahan Kota Paris, hal ini akan membuat penonton merasa tertarik untuk melihat kelanjutan Mini Drama ini karena terlihat dari scene awal yang mengekspose keindahan Kota Paris dan notabenenya Kota Paris merupakan salah satu Kota yang banyak digandrungi oleh masyarakat khususnya masyarakat di Indonesia.

\section{Scene 3}

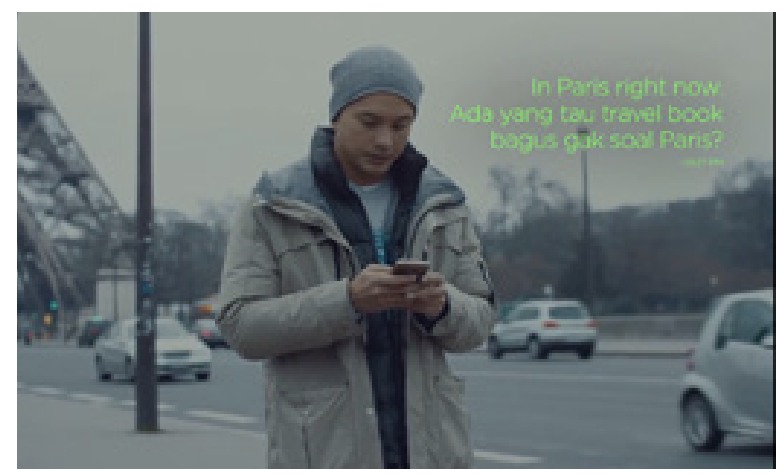

Gambar 2 scene tiga episode satu

\section{Level Realitas}

Scene ketiga dari episode pertama memperlihatkan penggunaan beberapa fitur dari instantmessaging Line. Nicberada di trotoar dengan memegangi ponsel untuk menghubungi beberapa temannya agar bisa membantu memandunya selama perjalanan liburannya di Paris. Nic menggunakan instant messaging Line untuk membantunya berkomunikasi dengan teman-temannya yang tidak sedang berada di Paris. Jika diidentifikasi scene memperlihatkan gambaran cara penggunaan instant messaging yang di campur dengan alur cerita, dengan cara ini penonton yang terhanyut dalam alur cerita akan menikmati scene ini sekaligus juga akan mengenal dan mengetahui beberapa fitur yang dimilki Line.

\section{Level Representasi}

Adegan dalam scene ini adalah $\mathrm{Nic}$ sedang berkirim pesan kepada temantemannya menggunakan ponselnya kemudian kamera mengambil gambar hanya ponsel Nic saja sehingga terlihat pesan-pesan yang Nic kirimkan pada teman-temannya. Berdasarkan pengaturan komposisi, dalam scene ini memiliki tujuan untuk mengarahkan perhatian penonton pada subjek dan objek yang terpenting. Dalam scene ini, hal tersebut dilakukan dengan gerak lensa zoom. Dengan gerak lensa zoom ini akan memberikan efek dramatis dan memberikan penjelasan apa yang sedang Nic lakukan saat menggunakan instant messaging Line.

\section{Scene 7}

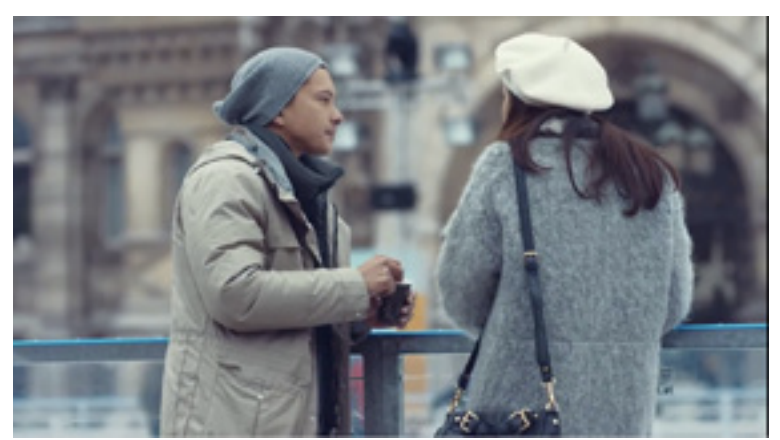

Gambar 3 scene tujuh episode satu 


\section{Level Realitas}

SceneketujuhdariepisodepertamaMini Drama Line Nic and Mar, mempertemukan Nic dengan aktris pemeran utama yaitu Mar yang diperankan oleh Mariana Renata. Mar datang dengan mengenakan sebuah coat tebal yang dihiasi syal di lehernya dan sarung tangan yang ia kenakan di kedua tangannya memiliki warna senada seperti coat nya. Mar mengenakan topi baret wanita berwarna putih ala senimanseniman Prancis tempo dulu. Tampilan Mar menunjukan gaya penampilan selayaknya pemuda Eropa yaitu gaya penampilan elegant namun tetap casual. Pemuda Eropa juga menyukai penampilang yang berbau klasik dan sederhana (dikutip dari www.id.wikihow.com tanggal 18 Maret 2016 pukul 15:21 WIB). Adegan yang memperlihatkan gaya penampilan orang Eropa tersebut diidentifikasi akan mampu menarik perhatian penonton karena mempertontonkan suatu kebiasaan dan kebudayaan Eropa yang cukup digandrungi masyarakat Indonesia, khususnya anak muda dan pada akhirnya penonton akan antusias menyaksikan kelanjutan dari mini drama ini.

\section{Level Representasi}

Terdapat dialog dalam scene tujuh. Sepenggal dialog dalam scene ini memberikan kesan bahwa Nic dan Mar memiliki kesibukan masing-masing yang berbeda. Walupun kesibukan dari Nic dan Mar berbeda, justru kesibukan mereka mampu mengantarkan mereka ke dalam pertemuan. Dua kegiatan pekerjaan yang berbeda yang bisa bertemu karena sebuah instant messaging.

\section{B. Episode 2}

Episode dua, dipilih satu scene untuk menjadi unit analisis. Scene tersebut yaitu scene sembilan.

\section{Scene 9}

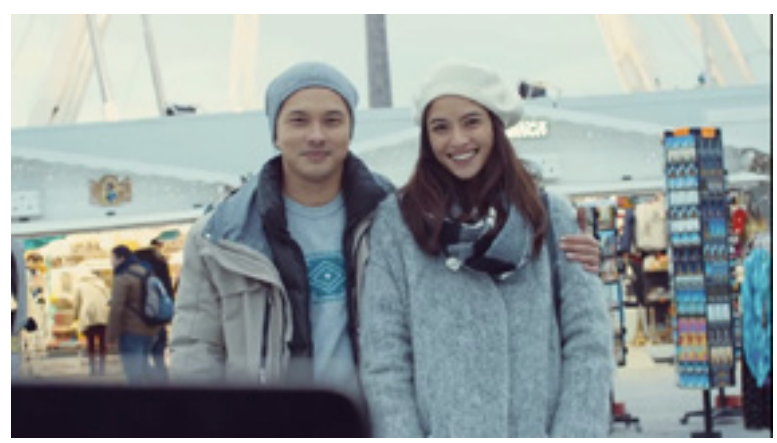

Gambar 4 scene sembilan episode dua

\section{Level Realitas}

Ekspresi dari mereka berdua dalam scene sembilan ini juga menunjukan mereka sedang bahagia. Emosi dan ekspresi menunjukan kebahagiaan ditunjukan dengan beberapa tanda dari anggota wajah seperti bagian bawah kelopak mata sedikit terangkat dan mata menyipit, kemudian bibir dan mulut terbuka dengan beberapa jejeran gigi terlihat dan juga pipi yang membesar dan memerah (Kumar, 2004). Ekspresi tersebut ditunjukan keduanya saat sedang berbincang satu sama lain, Mar beberapa kali justru tertawa dan Nic walaupun tidak tertawa namun dirinya memberikan senyuman yang lebar pada Mar.

\section{Level Representasi}

Pada scene ini terlihat Mar dan Nic berada di sebuah taman hiburan bermain. Hal itu terlihat dari beberapa toko-toko di belakang Nic dan Mar saat mereka berfoto. Toko-toko tersebut memiliki warna pada dinding mereka yaitu putih. Berbagai aksesoris dan barang-barang unik yang 
bisa dijadikan oleh-oleh khas Prancis dan dapat dibeli di toko-toko tersebut. Tempat tersebut juga tergambar sebagai taman hiburan karena dalam tempat tersebut terdapat sebuah ferish wheel besar yang dapat melihat pemandangan Kota Paris dengan menaikinya. Lampu-lampu dari toko-toko tersebut sudah menyala, dan langit sudah mulai gelap. Setting dalam scene ini tidak hanya mendukung alur cerita dari mini drama ini, namun setting dalam scene ini memperlihatkan tempat yang menarik di Kota Paris dan bisa menimbulkan keterkaitan tersendiri dengan emosi penonton. Emosi tersebut misalnya emosi senang karena dengan menyaksikan mini drama ini sekaligus dapat menikmati keindahan dari tempat-tempat di Kota Paris yang belum di ketahui penonton. Maka dengan begitu penonton akan senang untuk mengikuti kelanjutan mini drama ini.

\section{Episode 3}

Episode tiga, dipilih satu scene untuk menjadi unit analisis. Satu scene tersebut yaitu scene satu.

\section{Scene 1}

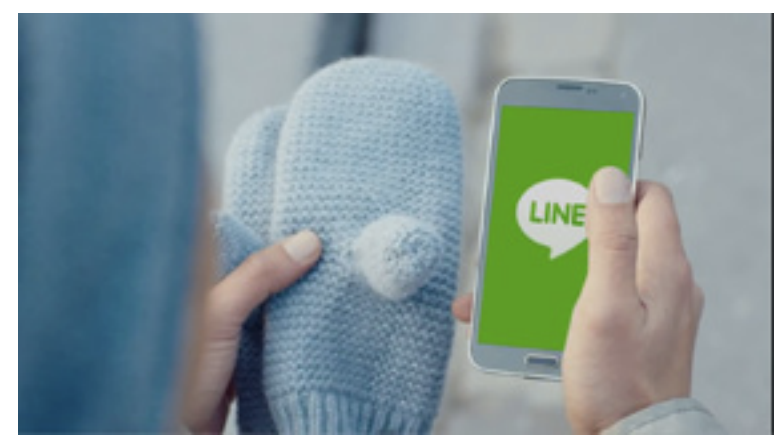

Gambar 5 scene satu episode tiga

\section{Level Realitas}

Pada scene ini terlihat Nic sedang memegangi ponsel ditangan kanannya sambil memegangi sarung tangan yang diberikan Mar di tangan kiri Nic. Sebelum memegangi ponsel di tangan kanan Nic, Nic memegang sarung tangan dan mengingat kebaikan Mar dan kondisi menyenangkan yang Nic dan Mar telah lalui. Nic mengeluarkan ponsel lalu membuka aplikasi instant messaging Line. Saat membuka instant messaging Line, para pengguna Line akan melihat logo Line dengan latar tema awalnya berwarna hijau. Dalam adegan tersebut Nic menyejajarkan ponselnya yang sedang membuka aplikasi Line dengan sarung tangan yang diberikan oleh Mar.

\section{Level Representasi}

Penggunaan musik dalam scene ini bernada mayor. Nada mayor akan menimbulkan kesan semangat dan ceria (Cheshire, 2011: 31). Pada scene ini Nic sedang memutar ingatannya bersama Mar. Ingatan Nic tentang Mar diperlihatkan menjadi sebuah ingatan yang manis karena didukung dengan musik pada scene ini yang memiliki nada mayor.

\section{Episode 4}

Episode empat, dipilih dua scene untuk menjadi unit analisis. Dua scene tersebut yaitu scene enam dan scene delapan.

\section{Scene 6}

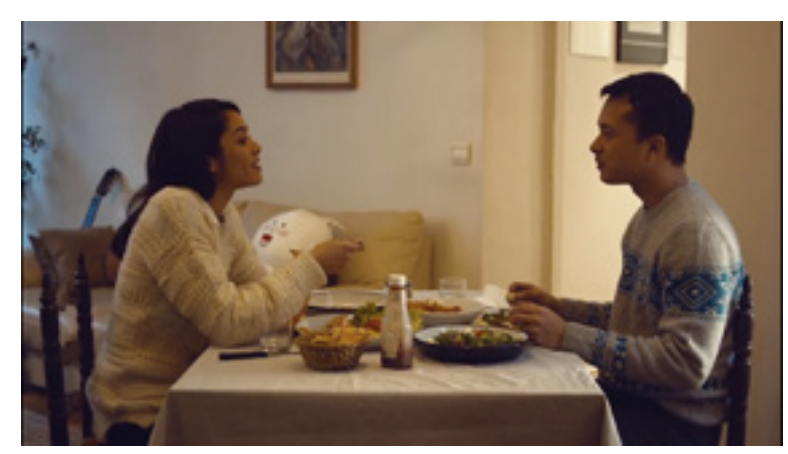

Gambar 6 scene enam episode empat 


\section{Level Realitas}

Dalam scene ini kedua tokoh melakukan aktifitas makan bersama. Aktifitas makan bersama yang dilakukan yaitu dilakukan dengan behavior yang biasa dilakukan oleh masyarakat Eropa khususnya Prancis. Orang Prancis biasa melakukan makan bersama dengan kerabatnya dengan memakan makanan khas Eropa seperti pasta, salad dan beberapa jenis protein (dikutip dari www.id.wikihow.com tanggal 18 Maret 2016 pukul 15:21 WIB). Adegan yang memperlihatkan tingkah laku orang Eropa tersebut diidentifikasi akan mampu menarik perhatian penonton karena mempertontonkan suatu kebiasaan dan kebudayaan Eropa yang cukup digandrungi masyarakat Indonesia, khususnya anak muda. Hal tersebut dikarenakan di Indonesia banyak anak muda yang menyukai kebiasaan budaya barat bahkan telah menjadi gaya hidup tersendiri bagi diri mereka.

\section{Level Representasi}

Pada scene ini Nic dan Mar berada dalam setting sebuah ruangan apartemen milik Mar. Nic dan Mar duduk di sebuah meja makan kecil. Di belakang tempat mereka duduk terdapat sofa berwarna putih dengan gitar yang bersandar di samping sofa. Di atas sofa terdapat sebuah boneka dengan ukuran yang cukup besar berwarna putih, boneka tersebut adalah boneka cony. Cony adalah karakter kelinci yang penuh ekspresi. Cony dikisahkan memiliki kekasih yangjuga dibuat karakter stiker Line, yaitu Brown (dikutip dari http://idws.id/ pada tanggal 15 Februari 2016 pukul 16:27). Suasana apartemen milik Mar memberikan kesan Mar merupakan wanita yang hidup sendiri, dengan meja makan yang kecil penataan yang sederhana namun rapi. Boneka cony yang di set tidak diperlihatkan secara utuh, namun tetap menarik perhatian akan memberikan kesan kegiatan seharihari lekat dengan Line.

\section{Scene 8}

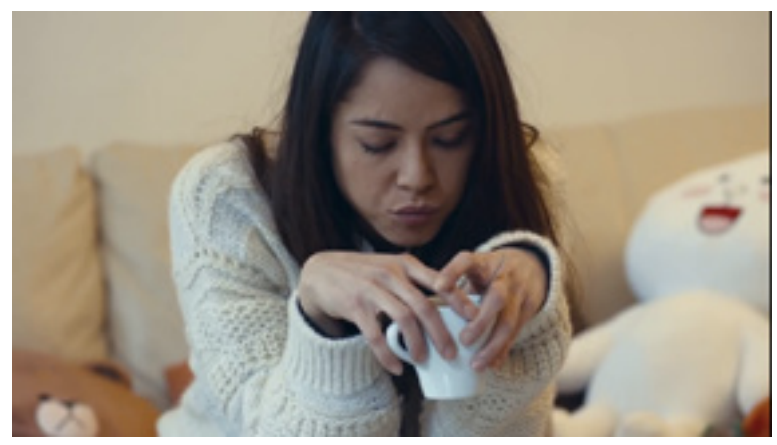

Gambar 7 scene delapan episode empat

\section{Level Realitas}

Pada scene ini Ekspresi Mar menunjukan ekspresi yang sedang dalam kebingungan. Matanya beberapa kali melirik kanan dan memandang ke bawah namun tidak fokus pada suatu hal, dengan kata lain pandangannya merupakan pandangan mengembara yang berarti dengan pandangan seperti itu merupakan pandangan sedang meneliti atau memikirkan sesuatu (Barbara, 1990). Mar bimbang, apakah dirinya akan ikut ajakan Nic untuk pergi ke Praha atau tidak.

\section{Level Representasi}

Musik dalam scene ini menggunakan nada minor. Nada minor yang mengisyaratkan suasana yang tidak begitu ceria dalam scene ini musik akan memberikan nuansa yang sedih. Sedih disini bukan berarti hal yang memiliki unsur kedukaan namun musik dengan nada minor pada scene ini mendukung suasana bimbang yang sedang dialami Mar. 


\section{E. Episode 5}

Episode lima, dipilih satu scene untuk menjadi unit analisis. Scene tersebut yaitu scene tujuh.

\section{Scene 7}

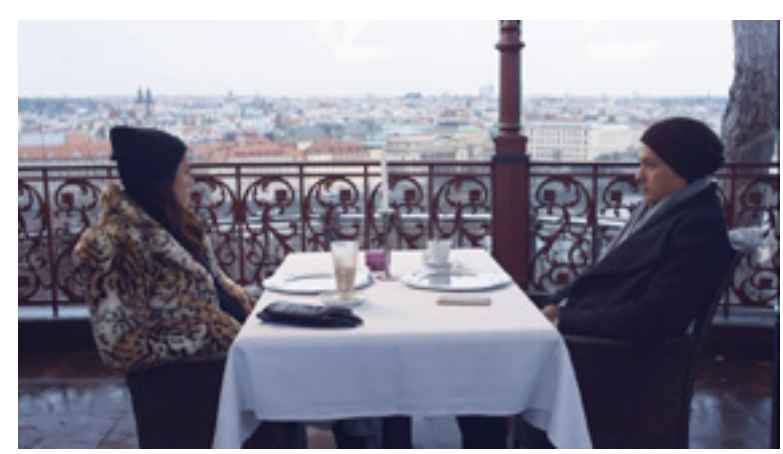

Gambar 8 scene tujuh episode lima

\section{Level Realitas}

Pada scene ini ekspresi yang ditunjukan oleh Mar saat melihat Nicyang mengobrol di telpon dan membuatnya tidak fokus menunjukan Mar sedang marah. Emosi marah ditunjukan dengan alis yang ditarik ke dalam, mata yang menatap tajam, bibir yang tertutup dan tidak memberikan senyuman (Kumar, 2004). Mar menunjukan emosi marah dengan gerak gerik wajahnya, hal ini menunjukan mereka mengalami sebuah konflik dalam situasi tersebut.

\section{Level Representasi}

Pada scene ini mereka berdua sedang makan di sebuah restaurant di Kota Praha. Meraka berada di meja makan di luar ruangan namun masih tetap di bagian restaurant tersebut. Nic dan Mar duduk di meja yang diberi taplak putih besar diatasnya dengan penataan peralatan makan yang rapi. Dari tempat Nic dan Mar duduk dapat melihat pemandangan Kota Praha dari atas. Ini menunjukan mereka makan di sebuah restaurant yang letaknya berada didaerahketinggian. Dari penataan setting yang seperti penjelasan di atas, scene ini memberikan kesan kemewahan dan menunjukan mereka berada di kelas sosial atas. Setting dalam scene ini diidentifikasi akan mampu menarik perhatian penonton karena memperlihatkan sebuah restaurant yang indah dengan penataan tempat dan pemandangan yang dapat dilihat dari restaurant tersebut. Hal tersebut dikarenakan di Indonesia banyak anak muda yang menyukai kebiasaan budaya barat bahkan telah menjadi gaya hidup tersendiri bagi diri mereka. Setting dalam scene ini memperlihatkan tempat yang menarik di Kota Praha dan bisa menimbulkan kertakaitan tersendiri dengan emosi penonton. Emosi tersebut misalnya emosi senang karena dengan menyaksikan mini drama ini sekaligus dapat menikmati keindahan dari tempat di Kota Praha yang belum di ketahui penonton. Maka dengan begitu penonton akan senang untuk mengikuti kelanjutan scene-scene dari mini drama ini.

\section{F. Episode 6}

Episode enam, dipilih dua scene untuk menjadi unit analisis. Dua scene tersebut yaitu scene empat dan scene sebelas.

\section{Scene 4}

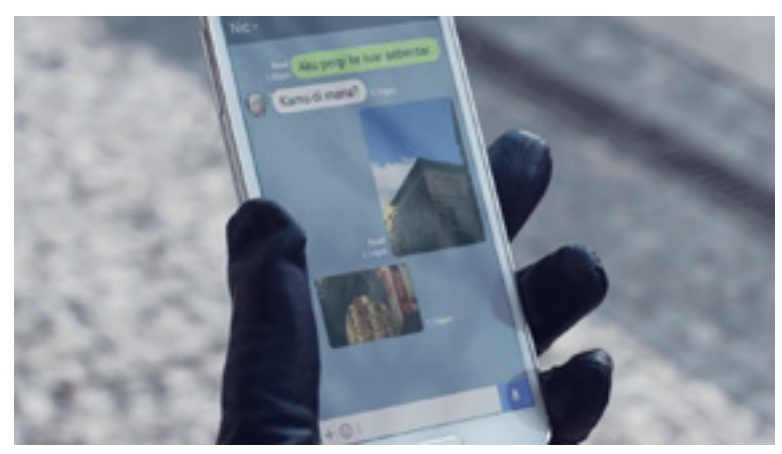

Gambar 9 scene empat episode enam 


\section{Level Realitas}

Pada scene ini Mar masih dalam kondisi yang marah kepada Nic. Mar meninggalkan pesan melalui Line kepada Nickarena dirinya ingin berpergian sendiri tanpa Nic. Nic yang merasa khawatir terhadap Mar mengikuti Mar dari belakang. Saat berada di persimpangan jalan Nic yang sebenarnya berada di belakang Mar mengirim pesan kepada Mar untuk menanyakan keberadaan Mar. Mar tidak menjawab namun hanya mengirimkan sebuah gambar, dan Nic membalas dengan mengirimkannya sebuah gambar juga. Mar mengirimkan gambar gedung yang ada di depannya, sementara Nic mengirimkan gambar Mar dari sisi belakang. Scene ini secara tidak langsung memberikan gambaran dari fitur-fitur yang dimiliki Line dan dengan bisa saja scene ini membuat penonton akan tertarik pada fitur yang dimiliki Line.

\section{Level Representasi}

Teknikpengambilangambarpadascene ini adalah eye level dengan ukuran gambar two shot. Dengan teknik pengambilan dan ukuran gambar seperti ini akan membuat penonton dapat memperlihatkan gesture mereka saat berada di jalan kecil Kota Praha. Namun, tidak hanya itu saja, beberapa kali dengan teknik ini juga dapat sekaligus memperlihatkan setting dimana Nic dan Mar melakukan scene ini. Namun beberapa kali juga menggunakan teknik pengambilan gambar eye level dan ukuran gambar medium shot untuk mengambil ekspresi dari Nic dan Mar.

\section{Scene 11}

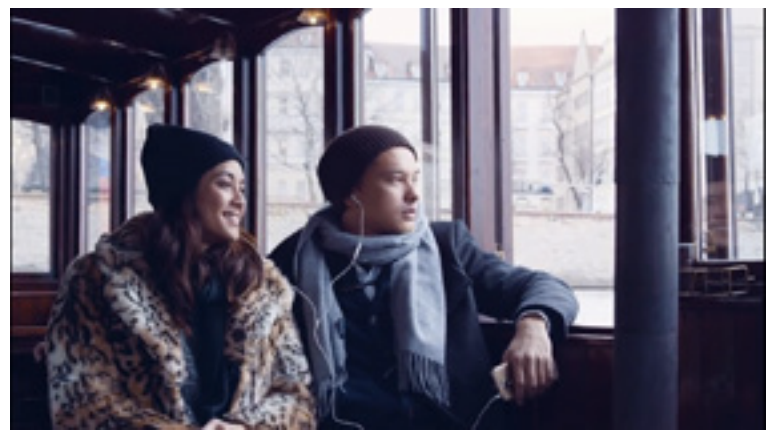

Gambar 10 scene sebelas episode enam

\section{Level Realitas}

Pada scene ini Nic dan Mar menaiki sebuah perahu menyusuri salah satu sungai di Praha. Nic menggunakan sebuah earphone untuk mendengarkan sebuah lagu, kemudian ia meminjamkan satu sisi earphone-nya agar bisa mendengarkan lagu bersama Mar. Scene ini menggambarkan behavior yang biasa dilakukan oleh orang Eropa. Orang Eropa memiliki sebuah kebiasaan untuk menyisikan waktu bukan untuk berbisnis tapi orang Eropa biasa menyisihkan waktu dalam hari mereka untuk menikmati banyak hal dnegan santai (dikutip dari www.id.wikihow.com tanggal 18 Maret 2016 pukul 15:21 WIB). Adegan yang memperlihatkan tingkah laku orang Eropa tersebut diidentifikasi akan mampu menarik perhatian penonton karena mempertontonkan suatu kebiasaan dan kebudayaan Eropa yang cukup digandrungi masyarakat Indonesia, khususnya anak muda.

\section{Level Representasi}

Teknik pengambilan gambar pada scene ini adalah eye level dengan ukuran gambar two shot. Dengan teknik pengambilan dan ukuran gambar seperti ini akan membuat penonton dapat memperlihatkan gesture dan ekspresi 
mereka saat berada di dalam prahu. Namun, tidak hanya itu saja, beberapa kali dengan teknik ini juga dapat sekaligus memperlihatkan setting dimana Nic dan Mar melakukan scene ini.

\section{G. Episode 7}

Episode tujug, dipilih dua scene untuk menjadi unit analisis. Dua scene tersebut yaitu scene empat dan scene sebelas.

\section{Scene 1}

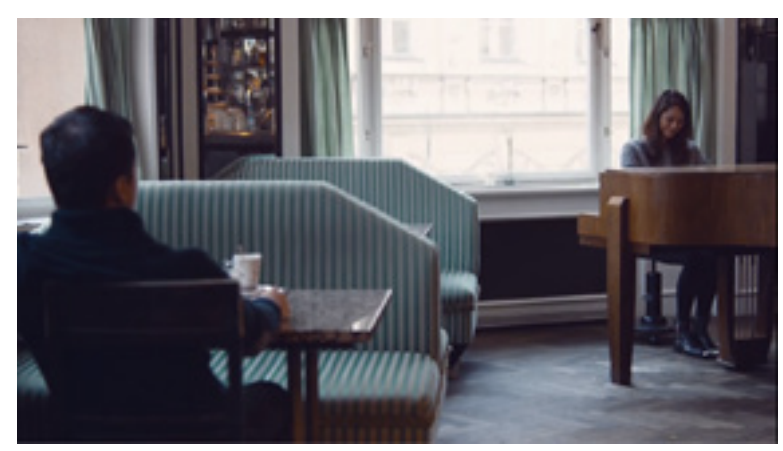

Gambar 11 scene satu episode tujuh

\section{Level Realitas}

Pada scene ini terlihat Nic dan Mar berada di sebuah café di Praha. Nic dan Mar memilih duduk dekat dengan pemain piano yang sedang memainkan piano di café tersebut. Mereka berdua menikmati minuman yang mereka pesan masing-masing. Sembari menikmati minuman, Nic meminta Mar untuk memainkan sebuah lagu dengan piano. Kemudian Mar memainkan piano dan Nic terus menatap Mar dari tempat ia duduk. Dalam gambar diperlihatkan Mar menikmati permainan pianonya.

\section{Level Representasi}

Adegan dalam scene ini adalah Nic dan Mar berada di sebuah restaurant di Praha. Berdasarkan pengaturan komposisi, dalam scene ini memiliki tujuan untuk mengarahkan perhatian penonton pada subjek dan objek yang terpenting. Dalam scene ini, hal tersebut dilakukan dengan gerak lensa zoom. Nic duduk di salah satu kursi di restaurant tersebut dan sedang memperhatikan Mar yang sedang bermain piano di depan tempat ia duduk, kamera mengambil gambar Nic dari jarak jauh kemudian Nic mengajukan pertanyaan untuk Mar, saat itu dilakukan pengambilan gambar dengan jarak dekat pada Mar dan membuat gambar ter close up. Dengan gerak lensa zoom ini akan memberikan efek dramatis pada ekspresi wajah Mar.

\section{Level Ideologi Dalam Mini Drama Line "Nic and Mar"}

Penulis menganalisis bahwa terdapat sebuah ideologi dibalik mini drama ini. Dimana Fiske (1987) memaparkan bahwa kode-kode sosial dan kode televisi membawa pesan kepada penonton dan keduanya akan tertanam dalam kode ideologis yang mereka bawa masingmasing. Posisi pembaca atau penonton adalah titik sosial dimana kode sosial, kode televisi, dan idelogi bercampur membentuk sesuatu yang koheren.

Saat dibuatnya mini drama ini pastilah melibatkan banyak pekerja kreatif yang membagi banyak ide-ide kreatif yang mereka miliki. Akan tetapi dibalik proses kreatif tersebut pasti terdapat kepentingankepentingan tersendiri dari media yang berkaitan, media dalam kasuskali ini adalah Line. Penulis menganalisis kepentingankepentingan yang berkembang dibalik pembuatan mini drama ini. Line sendiri merupakan sebuah aplikasi messaging yang dibuat oleh perusahaan NHN Corporation asal Korea Selatan. NHN Corporation juga mengoperasikan Naver, mesin cari online terbesar di Korea Selatan. Line diluncurkan pada 23 Juni 2011 dan tak terduga Line memang sangat diminati terbukti dari 
data yang dikutip dari www.bersosial. com tanggal 3 Maret 2016 pukul 07:06 WIB yang menyebutkan bahwa Pada bulan November 2012, pengguna Line sudah mencapai 74 juta di seluruh dunia. Dan pada 2 Mei 2013, penggunanya menembus angka 150 juta. Pasar terbesar Line adalah di negara-negara Asia termasuk Indonesia. Jika dilihat dari sudut pandang politik, pemilik Line sendiri yaitu Lee Hae Jin yang merupakan warga negara Korea tidak ada sangkut paut dibidang politik Indonesia.

Akan tetapi jika dilihat dalam bidang ekonomi, hal ini cukup menarik. Di awal penelitian ini diketahui bahwa Galuh Chandrakirana selaku team leader of marketing Line Indonesia menampik asumsi bahwa drama Nic and Mar merupakan sebuah kampanye pemasaran tertentu. Line hanya ingin membuat sebuah hiburan gratis yang bisa dinikamti penggunanya hanya dengan menggunakan gadget mereka masing masing. Disamping asumsi asumsi tentang Nic and Mar, faktanya drama ini mampu menyita banyak perhatian dari masyarakat Indonesia. Dalam waktu sembilan hari perluncuran drama Nic and Mar berhasil memperoleh 1,1 juta viewers dan meningkat setiap harinya. Dari peluncuran episode pertamanya Line mampu meningkatkan jumlah penggunanya sebanyak $14 \%$. Jika kita melihat dari segi awal munculnya Line yaitu 2011 dengan peningkatan penggunaan Line di seluruh dunia yang cukup signifikan, kemudian dikaitkan dengan siklus Product Life Cycle penulis menganalisis Line berada dalam tahap growth dimana berdasarkan yang penulis kutip dari http://ilmumanajemenindustri. com tanggal 3 Maret 2016 pukul 07:23 WIB tahap growth merupakan tahap tahap dimana produk yang diperkenalkan tersebut sudah dikenal dan diterima oleh konsumen dengan beberapa ciriciri pada tahap growth ini, seperti memperluas pasar, omset penjualan yang naik signifikan, meningkatnya kapasitas produksi, produk mulai diterima oleh pasar, cash flow mulai berubah menjadi positif, pasar semakin berkembang, laba juga akan meningkat, namun pesaingpesaing akan mulai bermunculan. Dalam tahap ini dianalisis munculnya pesaingpesaing disekitar bisnis, juga seperti kondisi yang dialami oleh Line.

Menurut data yang dilansir dari Global Web Index (GWI) dalam situs dailysocial. net diakhir tahun 2014 di Indonesia sendiri terdapat banyak instant messaging dan Line belum menduduki posisi pertama. Dalam top10 instant messaging di Indonesia Line menduduki posisi ke lima dengan bersaing tipis dibelakangnya yaitu KakaoTalk. Persaingan ketat dalam bisnis instant messaging juga menuntut banyak kreatifitas dari Line untuk mengantarkan produknya ke kepala target konsumennya. Dari latar belakang tersebut dapat dianalisis bahwa sebuah mini drama yang awal dibuatnya hanya untuk hiburan semata tanpa ada embel-embel kampanye pemasaran tertentu, hal ini tidak akan semurni itu terjadi mengingat latar belakang yang telah dipaparkan tadi, pasti ada unsur mengambil banyak keuntungan dari dibuatnya mini drama ini. Kepentingankepentingan yang ada dalam mini drama ini adalah kepentingan ekonomi bagi Line itu sendiri.

Berbicara tentang kepentingan ekonomi dibalik sebuah produk dan persaingan, penulis menganalisis bahwa terdapat ideologi kapitalisme dibalik pembuatan Mini Drama Line "Nic and Mar". Dalam sistem kapitalisme modern, produksi besar sejumlah barang 
ditujukan terutama untuk nilai tukarnya, yaitu memperoleh sejumlah uang yang menjadi keuntungan kekuatan kapitalisme atas barang-barang yang mereka jual di pasar. Didalam kapitalisme produksi dilakukan untuk dijual di pasar bukan untuk dikonsumsi sendiri (dalam Suyanto, 2013:81).

\section{Analisis Komodifikasi Isi Pesan dalam Aspek Audio Visual pada Mini Drama Line "Nic and Mar" Dapat Mewujudkan Nilai Guna Menjadi Nilai Tukar}

Dalam mini drama ini aspek visual dan aspek audio dibentuk berdasarkan pengaturan setting, pengambilan gambar, editing, pengaturan komposisi, pengaturan kontiniti, pembentukan ekpresi tokoh, pemilihan musik dan dialog sehingga menjadi sebuah tontonan, namun tandatanda yang ada di dalamnya diolah menjadi sebuah produk sehingga scene dalam mini drama ini dibentuk menjadi komoditas yang ditujukan untuk masyarakat. Perubahan fungsi pun terjadi, alur cerita yang berguna sebagai bagian pembentuk cerita mini drama ini kini juga berfungsi sebagai alat tukar karena seperti yang telah dijelaskan di atas, aspek audio dan visual sebagai pembentuk utama isi pesan mini drama ini telah dirasuki dengan item-item yang akan mengingatkan penonton pada karakteristik yang dimiliki Line. Proses komodifikasi sendiri menurut Vincent Mosco (1996) dinyatakan sebagai proses transformasi nilai guna menjadi nilai tukar.

\section{SIMPULAN}

Berdasarkan penelitian yang telah dilakukan peneliti terhadap Mini Drama Line "Nic and Mar", terdapat kesimpulan yang dapat diambil yaitu:
1) Bentuk komodifikasi isi pesan dalam aspek visual Mini Drama Line "Nic and Mar"

Perancangan setting dan pengambilan gambar dalam scenescene banyak memperlihatkan tentang karakteristik Line. Dari segi pengambilan gambar memperlihatkan secara jelas penggunaan fitur-fitur Line. Dari segi penampilan, sang aktor pertama kali muncul dengan mengenakan celana panjang berwarna hijau yang sedikit mencolok dari warna lain di sekitarnya. Bentuk-bentuk visual seperti ini dalam Mini Drama Line "Nic and Mar" cukup menarik perhatian saat menonton, hal-hal yang kontras dan seperti dihubunghubungkan dengan karakter instant messaging Line sehingga menarik pemikiran penonton pada instant messaging Line.

2) Bentuk komodifikasi isi pesan dalam aspek audio Mini Drama Line "Nic and Mar"

Bentuk audio disini berupa dialog dalam sebuah scene dalam mini drama ini. Dilalog tersebut diantara Nic dan Mar namun pemilihan kata dalam dialog tersebut tersirat mengajak semua orang yang menonton, bukan dialog yang dikhususkan hanya diantara mereka berdua saja. Maka secara tidak langsung, yang akan disadari adalah sebuah tindakan bukan hanya harus dilakukan Nic dan Mar namun semua orang juga harus melakukan hal seperti itu.

3) Komodifikasi Isi Pesan dalam Aspek Audio Visual pada Mini Drama Line “Nic and Mar" Dapat Mewujudkan Nilai Guna Menjadi Nilai Tukar 
Dalam mini drama ini aspek visual dan aspek audio dibentuk berdasarkan pengaturan setting, pengambilan gambar, editing, pengaturan komposisi, pengaturan kontiniti, pembentukan ekpresi tokoh, pemilihan musik dan dialog sehingga menjadi sebuah tontonan, namun tanda-tanda yang ada di dalamnya diolah menjadi sebuah produk sehingga scene dalam mini drama ini dibentuk menjadi komoditas yang ditujukan untuk masyarakat.

\section{SARAN}

Setelah melakukan penelitian dan melihat hasil analisi dari penelitian ini maka peneliti memberikan saran yaitu sebagai berikut:

1) Untuk para peneliti, penulis menyarankan agar lebih berkembang lagi dari segi penganalisaan aspekaspek pembentuk sebuah tayangan dengan cara banyak mencari referensireferensi terkait dengan kode sosial yang berhubungan dengan tayangan tersebut. Aspek-aspek yang berupa aspek audio dan visual bisa saja memiliki maksud-maksud tertentu sehingga menciptakan sebuah komodifikasi bagi tayangan itu sendiri.

2) Untukmediaagarlebihmemperhatikan manfaat dan dampak komodifikasi. Jika proses komodifikasi dimasukan kedalam sebuah tayangan mampu membawa dampak baik bagi media itu sendiri misalnya dalam bidang ekonomi maka proses komodifikasi tidak ada salahnya untuk dimasukkan kedalam sebuah tayangan. Hanya saja media juga perlu memperhatikan segi kreatifitas agar tayangan dapat dikemas menjadi sebaik mungkin sehingga menghasilkan tayangan yang berkualitas yang bisa digandrungi masyarakat. Diharapkan juga pihak media dapat memperhatikan dampakdampak lain dari komodifikasi sesuai dengan ideologinya.

\section{DAFTAR PUSTAKA}

Berger, Arthur Asa. (2012) Media Analysis Techniques. New York: Sage Publications.

Fiske, John. 1987. Television Culture. London: Routledge \& Metheun.

Fiske, John. (2006). Introduction to Communication Studies. London: Routledge \& Metheun.

Halim, Syaiful. (2012) Postkomodifikasi Media E Cultural Studies. Yogyakarta: Indie Book Corner.

McQuail, Dennis. (2011). Teori Komunikasi Massa. Jakarta: Salemba Humanika.

Moleong, Lexy J. (2012) Metodologi Penelitian Kualitatif. Bandung: PT Remaja Rosdakarya.

Morissan, (2010). Periklanan: Komunikasi Pemasaran Terpadu (Cetakan ke-1). Jakarta: Kencana.

Mosco, Vincent. (2009). The Political Economy of Communication (Edisi ke2). London: Sage Publication.

Mulyana, Deddy. (2007). Ilmu Komunikasi Suatu Pengantar (Cetakan ke-10). Bandung: PT Remaja Rosdakarya.

Nugroho, Sarwo. (2014) Teknik Dasar Videografi. Yogyakarta: Andi Offset

Sobur, Alex. (2009). Semiotika Komunikasi (Cetakan ke-4). Bandung: PT Remaja Rosdakarya.

Suyanto, Bagong. (2013). Sosiologi Ekonomi (Edisi ke-1). Jakarta: Kencana. 